\title{
Grupsal Polis Sapmasına Karşı Grupsal Polis Bütünlüğü Perspektifinden Kuzey Kıbrıs Türk Cumhuriyeti Polis Örgütü Üzerine Nicel Bir Araştırma*
}

\author{
A Quantitative Study on the Police Organization of the Turkish Republic of Northern Cyprus from the \\ Group Police Integrity Perspective Against Group Police Deviance
}

Osman KAYABAŞI

Dr., KKTC Polis Teşkilatı,

osmankayabasi@yahoo.com

https://orcid.org/0000-0001-9499-5974
Makale Başvuru Tarihi: 30.01.2021

Makale Kabul Tarihi: 03.04.2021

Makale Türü: Araştırma Makalesi

Anahtar
Kelimeler:
Polis Bütünlüğ̈̈,
Polis Sapmasl,
Grupsal Polis
Bütünlüğ̈̈,
Grupsal Polis
Sapmasl,
KKTC Polis
Örgütü,
Keywords:
Police Integrity,
Police Deviance,
Group Police
Integrity,
Group Police
Deviance,
TRNC Police
Organization,

ÖZET

Bu araştırma, Kuzey Kıbrıs Türk Cumhuriyeti (KKTC) Polis Örgütünde görevli polislerin, polis sapmasına karşı polis bütünlüğ̈̈ düzeylerinin grupsal özelliklerine göre anlamlı bir şekilde farklılaşıp farklılaşmadığını karşılaştırmak ve ĕger anlamlı bir fark varsa bu farkın hangi gruplar arasında olduğunu ortaya çıkarmak amacıyla yapılmıştır. KKTC Polis Örgütü, büyük gruplardan küçük gruplara doğru üç seviyede ele alınarak karşılaşstırllmıştır. Karşılaş̧tırllan gruplar; (1) merkez örgütü ile taşra örgütü, (2) ilçe polis müdürlükleri ve (3) polis birimleridir. Araştırma tarama türündedir. Veri toplama tekniği olarak anket kullanılmıştır. Araştırmanın evrenini KKTC Polis Örgütünde görevli 1926 polis; örneklemini ise 1767 polis oluşturmaktadır. Araştırma sonuçları, grupsal boyutta polis bütünlüğü düzeylerinin her üç katmanda da farklılaştığını; merkez örgütünün taşra örgütünden, Gazimağusa Polis Müdürlüğünün diğer İlçe Polis Müdürlüklerinden ve "siyasi/istihbarat" birimlerinin diğer polis birimlerinden genel olarak daha fazla polis bütünlüğüne sahip olduklarını ortaya çıkarmıştır. Çalışmanın sonuç kısmında KKTC Polis Örgütünün grupsal polis bütünlüğ̈̈nü artırmak için neler yapılabileceği ile ilgili öneriler sunulmuştur.

\section{ABSTRACT}

This research was carried out to compare whether the police integrity levels of the police officers working in the Turkish Republic of Northern Cyprus (TRNC) Police Organization differ significantly according to their group characteristics and, if there is a significant difference, to reveal between which groups this difference is. TRNC Police Organization has been handled and compared in three levels from large groups to small groups. These groups are; (1) central organization with provincial organization, (2) district police directorates and (3) police units. The research is in survey model. Questionnaire was used as data collection technique. The universe of the research is the 1926 police officer in the TRNC Police Organization, whereas the sample is 1767 police officers. The research results show that police integrity levels of the groups differed in all three layers; it also revealed that in general, there is more police integrity in central organization than provincial organization, more in Famagusta Police Directorate than other district police directorates, and more in political/intelligence units than other units. In the conclusion part of the study, suggestions about what can be done to increase the group police integrity of the TRNC Police Organization are presented.
\end{abstract}

* Bu makale, yazar tarafindan 2019 yılında Polis Akademisi Güvenlik Bilimleri Enstitüsü’nde sunulan ve kabul edilen “Polis Sapmasına Karşı Polis Bütünlü̆̈̈̈ Perspektifinden Kuzey Kıbrıs Türk Cumhuriyeti Polis Örgütü” başlıklı doktora tezinden yararlanılarak hazırlanmıştır. Makale, 18-20 Aralık 2020 tarihleri arasında Bosna Hersek’te Gorazde Üniversitesi ev sahipliğinde düzenlenen Uluslararası CEO (İletişim, Ekonomi, Organizasyon) Sosyal Bilimler Kongresinde sözlü bildiri olarak sunulmuştur. 


\section{GİRiş}

KKTC Polis Örgütünde görevli polislerin, polis sapmasına karşı polis bütünlüğ̈ düzeylerinin grupsal özelliklerine göre anlamlı bir şekilde farklılaşıp farklılaşmadığını karşılaştırmak ve eğer anlamlı bir fark varsa bu farkın hangi gruplar arasında olduğunu ortaya çıkarmak amacıyla yapılan çalışma "polis bütünlüğü" ve "polis sapması" kavramları üzerine tesis edilmiştir. Polis bütünlüğü (Kayabaşı, 2020b:350);

"Polisin; mesleki mevzuata, polis etiğine ve mesleki değerlere uygun davranması, davranışlarını içten gelerek, inanarak sergilemesi, söylediği sözlerin ve sergilediği davranışların tutarlı olması, mesleğe aykirl davranmaya sevk eden ayartmalara, mesleki sapma ve yozlaşmaya karşı direnç göstermesi ve bunların tümünü barındıran sağlam bir karaktere sahip olmasıdır."

Polis bütünlüğüne sahip polislerin, görevlerini yerine getirir ve yetkilerini kullanırlarken hukuka uygun kararlar vermeleri, verdikleri kararlar ile aynı doğrultuda sözler, eylemler, tutum ve davranışlar sergilemeleri ve mesleklerini bir bütünlük içerisinde icra etmeleri gerekmektedir. Bu şekilde hareket etmekle, örgütsel düzeyde mensubu oldukları polis örgütlerinin, grupsal düzeyde çalıştıkları polis birimlerinin/gruplarının ve bireysel düzeyde bir polis olarak kendilerinin polis bütünlüğünü korumuş olacaklardır. İç güvenliği sağlamak ve korumakla görevli ve aynı zamanda ceza adalet sisteminin de ilk halkası olan polisin bütünlügünü koruması, toplumda güven ve adalet duygusunun sağlanması, korunması, yerleşmesi ve sürdürülmesi bakımından tartışılmaz bir öneme sahiptir (Kayabaşı, 2019:1-2).

Polis sapması, "polisin, mesleğinin etik kurallarına, çalıştığı birimdeki yetki ve görevlerine ve mensubu olduğu polis örgütünün kural, politika ve prosedürlerine aykırl davranışlar sergilemesidir" (Kayabaş1, 2020c:266), şeklinde tanımlanmaktadır. Polis bilimleri literatüründe polis sapmasının yaygınlığının, bireysel boyutta olduğu tezi "çürük elma (rotten apple)" teorisiyle (Knapp Komisyonu, 1972), grupsal boyutta olduğu tezi "çürük varil (rotten barrel)" teorisiyle (O'Connor, 2005:2), örgütsel boyutta olduğu tezi ise "çürük meyve bahçeleri (rotten orchards)" teorisiyle (Punch, 2003:172) tasvir edilmektedir.

Polis bütünlüğünün ihlal edilmesi, diğer bir ifadeyle polis sapması, sergilenen sapma davranışının türüne, polis akran grubunun söz konusu sapma davranışına tahammül göstermeme düzeyine, sapmanın gerçekleştirildiği ortama, karşıllaşılabilecek disiplin işlemine veya adli işleme ve meslektaşları tarafından ihbar edilme olasılığına göre değişkenlik gösterebilmektedir (Kayabaşı, 2019:3). Polis sapması, her ülkenin polis örgütünde görülebilen küresel bir sorun olarak varlığını sürdürmektedir.

KKTC özelinde polis sapması sorununa bakıldığında; KKTC'deki çeşitli mahkeme kararları, Meclis Araştırma Komitesi raporları, KKTC Bakanlar Kurulunun KKTC Polis Örgütüne yönelik özel soruşturmacı ataması kararı, Türkiye İnsan Hakları Derneği yayınları, KKTC Polis Örgütünün yıllık faaliyet raporları ve basına yansıyan polis sapması ile ilgili çeşitli haberler KKTC'deki polis sapmasının varlığını belgeler niteliktedir.

2012 yılında KKTC'de kamu çalışanlarının, kamu yönetimi, çalışma koşulları ve kamu reformu konusundaki tutumlarını ortaya koymaya yönelik gerçekleştirilen 'Kuzey Kıbrıs Kamu Çalışanları Araştırması'nın sonuçları, KKTC kamu personel sisteminin birinci sırada en önemli sorununun "yolsuzluk/rüşvet/kayırmacıllı" olduğunu ortaya çıkarmıştır (KKTC Fokus, 2012:124).

KKTC Polis Örgütünün halk tarafından nasıl algılandığına yönelik "polis etiği”" (Kayabaşı O., 2012; Kayabaş1 ve Tekiner, 2017a) ve "polis meşruiyeti" (Kayabaşı C., 2012:2020) üzerine çalışmalar yapıllmıştır. Son yıllarda KKTC'de polis bütünlüğü üzerine bir takım çalışmalar yapılmakla birlikte, sorunun grupsal boyutta incelenmesine odaklanan herhangi bir çalışmanın yapılmadığı görülmektedir.

Araştırma ile polislerin gruplar arası polis bütünlüğü düzeylerinin karşılaştırılmasına odaklanılmış ve KKTC Polis Örgütünde görevli polislerin, polis sapmasına karşı polis bütünlüğü düzeylerinin farklı seviyelerdeki grupsal boyutta anlamlı bir şekilde farklılaşıp farklılaşmadığı ve eğer anlamlı bir şekilde farklılaşmışsa bu farkın hangi gruplardan kaynaklandığı araştırılmıştır. Bu çerçevede KKTC Polis Örgütünün;

(1) Merkez örgütü ile taşra örgütü,

(2) İlçe polis müdürlükleri (Lefkoşa, Gazimağusa, Girne, Güzelyurt ve İskele ilçeleri Polis Müdürlükleri),

(3) Polis birimleri (İdari [Karakol], Adli, Trafik, İdari Işsler ve Özlük İşleri, Muhaceret, Güvenlik-Koruma, İletişim Bilgi Iş̧lem, Özel Harekât, Siyasi/İstihbarat, Narkotik ve Kaçakçılı̆̆ı Önleme) kendi aralarında karşılaştırılmıştır. 


\section{ARAŞTIRMANIN KKTC POLİS ÖRGÜTÜ ÜZERINDE UYGULANMASI}

Çalışmanın bu kısmında, yapılan araştırmanın konusuna, amacına, önemine, teknik kavramlarına, evren ve örneklemine, temel sorunsalı ve hipotezlerine, veri toplama aracına, kısitlarına ve akademik yazında bu konudaki literatüre yer verilmiştir.

\subsection{Araştırmanın Konusu}

$\mathrm{Bu}$ araştırmanın konusu, KKTC Polis Örgütünde görevli polislerin polis bütünlüğü düzeylerinin, grupsal özelliklerine göre anlamlı bir şekilde farklılaşıp farklılaşmadığının incelenmesidir. Bu çerçevede KKTC Polis Örgütünde görevli polislerin polis sapmasına karşı polis bütünlügü düzeylerinin grupsal özelliklerine göre anlamlı bir şekilde farklılaşıp farklılaşmadığı karşılaştırılacak ve eğer anlamlı bir fark varsa bu farkın hangi gruplar arasında olduğu bilimsel verilerle ortaya konulacaktır. Karşılaştırılan büyük seviyedeki gruplar; merkez örgütü ve taşra örgütü, orta seviyedeki gruplar; beş ilçe polis müdürlüğü ve küçük seviyedeki gruplar; İdari (Karakol), Adli, Trafik, İdari İşler ve Özlük İşleri, Muhaceret, Güvenlik-Koruma, İletişim Bilgi İşlem, Özel Harekât, Siyasi/İstihbarat, Narkotik ve Kaçakçılığı Önleme birimleridir.

\subsection{Araştırmanın Amacı ve Önemi}

Bu araştırma, KKTC Polis Örgütünde görevli polislerin, polis sapmasına karşı polis bütünlüğü düzeylerinin grupsal özelliklerine göre anlamlı bir şekilde farklılaşıp farklılaşmadığını karşılaştırmak ve eğer anlamlı bir fark varsa bu farkın hangi gruplar arasında olduğunu ortaya çıkarmak amacıyla yapılmıştır. Bu çalışma, aynı polis örgütü içerisinde farklı seviyelerdeki farklı polis gruplarında polis bütünlüğü düzeylerinin de farklılaşabileceğini göstermektedir ki bu bulguların literatüre önemli bir katkı sağlayacağı değerlendirilmektedir. Çalışmanın alanda yapılacak sonraki çalışmalara, sorunun grupsal yönünün de var olduğunu gösteren farklı bir bakış açısı kazandıracağı umulmaktadır. Çalışma bulgularının, iç güvenlik yöneticilerinin, polislerin sapma davranışlarını önlemeye ve polis bütünlüğü düzeylerini artırmaya yönelik geliştirecekleri stratejilere ve politikalara yardımcı olacağı da değerlendirilmektedir.

\subsection{Araştırmada Kavramsal ve Kurgusal Metodolojisi}

Araştırma kapsamında kullanılan "Grupsal Polis Bütünlüğü” kavramı, yukarıda açıklanan "polis bütünlüğü” kavramının grupsal açıdan ele alınması ve yine "Grupsal Polis Sapması" kavramı da "polis sapması" kavramının grupsal açıdan değerlendirilmesi şeklindedir. Polis sapma davranışı türlerinden; "uygunsuz ikinci iş yapma/ticari faaliyette bulunma" Senaryo 1'de (Görev haricinde güvenlik sistemi işi yapma); “otorite yozlaşması" Senaryo 2 (Esnaftan bedava yiyecek, içecek kabulü) ve Senaryo 4'te (Esnaftan bayram, yılbaşı hediyesi kabulü); "rüşvetçilik' Senaryo 3'te (Hız yapan motosiklet sürücüsünden rüşvet alma); 'firsat hırsızlığı' Senaryo 5 (Olay mahallinden saat hırsızlığı) ve Senaryo 11'de (Bulunan cüzdan içerisinden hırsızlık); 'komisyonculuk' Senaryo 6'da (Oto tamircisinden \%5 komisyon alma); 'kurum içi rüşvet ilişkisi' Senaryo 7'de (Amirin, şahsi aracına bakım yapması karşılı̆̆ı memuruna tatil izni önermesi); 'kılıfına uydurma/kapatma' Senaryo 8'de (Alkollü meslektaş kazasını rapor etmeme); 'yasa dışı faaliyetleri koruma' Senaryo 9'da (Barın kapanma saatini görmezden gelip bedava içki kabulï) ve 'sivillere karşı polis şiddeti' ise Senaryo 10'da (Araba hırsızına karşı aşırı güç kullanımı) tasvir edilmiştir.

\subsection{Araştırmanın Evren ve Örneklemi}

KKTC Polis Örgütünün insan kaynakları; polisler, itfaiyeciler ve sivil hizmet görevlilerinden oluşmaktadır. Bu araştırmanın evrenini, KKTC Polis Örgütünde çalışmakta olan polisler oluşturmaktadır. Anketin uygulandığ 1 dönemde (15 Haziran 2015- 15 Eylül 2015), 31 Temmuz 2015 tarihindeki KKTC Polis Örgütündeki polis sayıs1 1926 idi. Araştırmada örneklem büyüklüğünün tespitinde; 'seçkisiz olmayan örnekleme' (olasılıklı olmayan, tesadüfi olmayan) (non-random sampling) yöntemlerinden biri olan 'amaçlı örnekleme' (purposive sampling) yönteminin 'ölçüt örnekleme' (criterion sampling) yöntemi kullanılmıştır (Büyüköztürk, 2012:11; Gürbüz ve Şahin, 2016:133-134). Bu çerçevede araştırmanın örneklemini KKTC Polis Örgütünün Polis Okulu, Denetleme Kurulu ve ARGE birimi haricindeki tüm merkez ve taşra örgütlerinde görevli polis memurları (1419), polis 
çavuşları (241) ve müfettiş muavinleri (107) olmak üzere toplam 1767 polis oluşturmaktadır. Bu ölçütler çerçevesinde oluşturulan örneklem, evrenin \%91,75'ini kapsamaktadır. Yapılan analizler sonucunda, evrenin (1926) \%91,75'ini oluşturan örneklemin (1767), \%65,76'sı (1162) tarafından cevaplandırılan anketler geçerli olarak değerlendirilmiştir.

\subsection{Araştırmanın Temel Sorunsalı ve Hipotezleri}

Araştırmanın cevap aradığı ana soru; "KKTC Polis Örgütünde görevli polislerin polis sapmasına karşı polis bütünlüğü düzeyleri grupsal özelliklerine göre anlaml bir şekilde farklllaşmakta mıdır?”, şeklinde tasarlanmıştır. Araştırma kapsamında aşağıda belirtilen hipotezler test edilmiştir.

H1: KKTC Polis Örgütünün Merkez Örgütünde çalışan polislerin polis bütünlüğü düzeyleri, Taşra Örgütünde çalışan polislerin polis bütünlüğü düzeylerinden anlamlı bir şekilde daha yüksektir.

H2: KKTC Polis Örgütü polislerin polis bütünlüğü düzeyleri, çalıştıkları İlçe Polis Müdürlüklerine göre anlamlı bir şekilde farklılık göstermektedir.

H3: KKTC Polis Örgütü polislerin polis bütünlüğ̈̈ düzeyleri, çalıştıkları birimlere göre anlamlı bir şekilde farkl111k göstermektedir.

\subsection{Araştırmanın Veri Toplama Aracı}

Araştırmada veri toplama aracı olarak anket kullanılmıştır. Polis bütünlügünü ölçmek için nasıl bir anket ve dolayısıyla ölçek kullanılabileceğine karar verilirken, öncelikle Türkçe literatür taranmış ve polis bütünlügünü ölçen herhangi bir ölçeğin Türkçe literatürde henüz geliştirilmediği saptanmıştır. Bunun üzerine İngilizce literatür taranmış ve Klockars ve arkadaşları tarafından geliştirilen "Polis Bütünlüğü Ölçeğì" (Klockars vd., 2006:14-15) Türkçe'ye ve KKTC koşullarına uyarlanarak kullanılmıştır. Polis bütünlüğü ölçeğinin Türkçeye ve KKTC koşullarına uyarlanmasında Uluslararası Test Komisyonu tarafından geliştirilen yöntem temel alınmıştır (International Test Commission, 2005). Bu çerçevede KKTC Polis Örgütünde görevli 40 kişilik bir polis grubuna öntest yapılmıştır. İç tutarlılığı tespit etmek amaciyla ölçekte yer alan 77 sorunun standardize edilmiş Cronbach Alpha Korelasyon Katsayısı hesaplanarak 0,927 değeri elde edilmiş ve ölçek ile ilgili güvenilirlilik figürlerinin yüksek düzeyde olduğu saptanarak ölçeğin uyarlanması gerçekleştirilmiştir (Kayabaş1, 2019:20). Bu ölçekte 11 adet varsayımsal senaryo ve her bir senaryonun altında, senaryoları değerlendirmek üzere tasarlanan aynı yedi adet soru yer almaktadır.

On bir farklı polis sapma davranışını tasvir eden senaryolar özetle şunlardır: Senaryo 1: Görev haricinde güvenlik sistemi işi yapma; Senaryo 2: Esnaftan bedava yiyecek, içecek kabulü; Senaryo 3: Hız yapan motosiklet sürücüsünden rüşvet alma; Senaryo 4: Esnaftan bayram, yılbaşı hediyesi kabulü; Senaryo 5: Olay mahallinden saat hırsızlı̆̆ı; Senaryo 6: Oto tamircisinden \%5 komisyon alma; Senaryo 7: Amirin, şahsi aracına bakım yapması karşıllı̆ı memuruna tatil izni önermesi; Senaryo 8: Alkollü meslektaş kazasını rapor etmeme; Senaryo 9: Barın kapanma saatini görmezden gelip bedava içki kabulü; Senaryo 10: Araba hırsızına karşı aşırı güç kullanımı ve Senaryo 11: Bulunan cüzdan içerisinden hırsızlık. Araştırma kapsamında, 11 farklı polis sapma davranışının her biri ile ilgili polislerin direnci, yani polis bütünlüğü, yedi farklı soru ile yedi farklı yönden ölçülmüştür.

Katılımcılardan, her bir senaryoyu gözden geçirdikten sonra, her bir senaryonun altındaki ilk değerlendirme sorusu ile, senaryolarda tasvir edilen polis sapma davranışlarını ne derece ciddi bir sorun olarak gördüklerini değerlendirmeleri istenmiştir. ${ }^{1}$ İkinci değerlendirme sorusu ile katılımcılardan, senaryolarda tasvir edilen polis sapma davranışlarını, çalıştıkları şubedeki polis mensuplarının çoğunun ne derece ciddi bir sorun olarak gördüklerini değerlendirmeleri istenmiştir. ${ }^{2}$ Katılımcılardan, bu iki değerlendirmeyi yaparken; "hiç de ciddi değil"den (1), "çok ciddi”ye (5) kadar uzanan beşli Likert ölçeğinden bir cevap seçmeleri istenmiştir.

Her bir senaryonun altındaki üçüncü değerlendirme sorusu ile katılımcılara, senaryolarda tasvir edilen polis sapma davranışlarının, çalıştıkları şubede, kurumlarının bu konudaki resmi politikasının ihlali şeklinde

1 Bu soru şu kelimelerle ifadelendirilmiştir: "SİZ bu davranışın ne kadar ciddi bir sorun olduğunu düşünürsünüz?"

$2 \mathrm{Bu}$ soru şu kelimelerle ifadelendirilmiştir: "ÇALIŞTIĞINIZ ŞUBEDEKI POLIS MENSUPLARININ ÇOĞU bu davranışın ne kadar ciddi bir sorun olduğunu düşünür?" 
yorumlanıp yorumlanmayacağı sorulmuştur. ${ }^{3}$ Katılımcılardan, bu değerlendirmeyi yaparken; "kesinlikle hayır" (1) ile "kesinlikle evet" (5) arasında değişen, beşli Likert ölçeğinden bir cevap seçmeleri istenmiştir.

Her bir senaryonun altındaki dördüncü değerlendirme sorusu ile katılımc1lardan, senaryolarda tasvir edilen sapma davranışlarında bulunan bir polise eğer bir disiplin işlemi uygulanacaksa kendilerine göre hangi disiplin işleminin uygulanması gerektiğini cevap seçenekleri arasından seçmeleri istenmiştir. ${ }^{4}$ Beşinci değerlendirme sorusu ile de katılımcılardan, senaryolarda tasvir edilen sapma davranışlarında bulunan bir polise eğer bir disiplin işlemi uygulanacaksa kurumları tarafindan hangi disiplin işleminin uygulanmasını beklediklerini cevap seçenekleri arasından seçmeleri istenmiştir. ${ }^{5}$ Katılımcılardan, bu iki değerlendirmeyi yaparken; (1) "hiçbir şey", (2) "sözlü ikaz", (3) "uyarma", (4) "kınama", (5) "kademe ilerlemesini durdurma" ve (5) "meslekten çıkarma veya rütbe indirimi" seçenekleri arasından bir cevap seçmeleri istenmiştir.

Katılımcılara, her bir senaryonun altındaki altıncı değerlendirme sorusu ile, senaryolarda tasvir edilen polis sapma davranışlarını sergileyen meslektaşlarını üstlerine bildirip bildirmeyecekleri sorulmuştur. ${ }^{6}$ Son olarak yedinci değerlendirme sorusu ile katılımcılara, senaryolarda tasvir edilen polis sapma davranışlarını sergileyen bir meslektaşlarını, çalış̧ıkları şubedeki polislerin çoğunun üstlerine bildirip bildirmeyecekleri hakkındaki düşünceleri sorulmuştur. ${ }^{7}$ Katılımcılardan, bu iki soru ile ilgili değerlendirmeyi yaparken, "kesinlikle hayır" (1) ile "kesinlikle evet" (5) arasında değişen, beşli Likert ölçeğinden bir cevap seçmeleri istenmiştir. Bu çerçevede polis bütünlügünün ölçüldüğü yönler şunlardır: Polislerin polis sapma davranışlarına karşı; (1) kendi ciddiyet algıları, (2) kendilerine göre meslektaşlarının ciddiyet algıları, (3) resmi kural ihlali algıları, (4) destekledikleri disiplin işlemi, (5) bekledikleri disiplin işlemi, (6) kendi bildirme isteklilikleri ve (7) kendilerine göre meslektaşlarının bildirme isteklilikleri.

\subsection{Araştırmanın Kısıtları}

Araştırma, çeşitli polis sapma davranışlarının tasvir edildiği 11 adet senaryo, anketin uygulandığı zaman dilimi (15 Haziran 2015- 15 Eylül 2015) ve KKTC Polis Örgütündeki polis memuru, polis çavuşu ve müfettiş muavini rütbelerindeki polis mensupları ile sınırlıdır.

\subsection{Literatür İncelemesi}

İngilizce literatürde polis sapması ve polis bütünlüğü üzerine çok sayıda çalışma yapılmıştır. ${ }^{8}$ Bu alanda yapılan çalışmaların bir kısmında polis sapmasına alternatif bir yaklaşım olarak polis bütünlügünün ölçümü ve karşılaştırılması amaçlanmıştır. Polis bütünlüğünü ölçmeye ve karşılaştırmaya odaklanan çalışmaların çoğunda Klockars ve arkadaşları tarafından geliştirilen polis bütünlüğü anketinin birinci ve ikinci versiyonlarının kullanıldığı görülmektedir. ${ }^{9}$ Türkçe literatür incelendiğinde, polis sapması (Kayabaşı, 2020c) ve polis bütünlüğü (Kayabaşı, 2020b) üzerine teorik çalışmaların yapıldığı görülmektedir. Türkçe literatürde polis bütünlügünün ölçümü ve karşılaştırılması üzerine de bir takım çalışmalar yapılmıştır. Klockars ve arkadaşları tarafından geliştirilen polis bütünlüğü anketinin birinci versiyonu ile KKTC Polis Örgütüne bağli ilçe polis müdürlüklerinden biri olan Güzelyurt Polis Müdürlüğünün polis bütünlüğü düzeyini ölçen (Kayabaş1, 2018c), KKTC Polis Örgütü ile Lefke Polis Karakolunun polis bütünlüğü düzeylerini karşılaştıran (Kayabaşı, 2020a) ve örgütsel, grupsal ve bireysel boyutları ile bir bütün olarak KKTC Polis Örgütünün polis bütünlügünü ele alan (Kayabaşı, 2019) çalışmalar yapılmıştır. Ayrıca anketin birinci versiyonu kullanılarak KKTC'deki polis bütünlüğünün diğer ülkelere nazaran ne durumda olduğunu tespite yönelik, KKTC'nin sekiz ülke ile karşılaştırılmasına odaklanan bir çalışma (Kayabaşı, 2020d) da yapılmıştır. Anketin ikinci versiyonu KKTC Polis Örgütünün merkez örgütünün polis bütünlügünü ölçmek (Kayabaş1, 2017a; Kayabaş1 ve Tekiner, 2017b),

$3 \mathrm{Bu}$ soru şu kelimelerle ifadelendirilmiştir: "Sizin çalıştığınız şubede bu davranış kurumun bu konudaki resmi politikasının ihlali şeklinde yorumlanır mı?"

$4 \mathrm{Bu}$ soru şu kelimelerle ifadelendirilmiştir: "Çalıştı̆̆ınız şubedeki bir polis mensubunun böyle bir davranışta bulunması ve bu davranışının ortaya çıkması durumunda, eğer bir disiplin işlemi uygulanacaksa, SïZCE hangi disiplin işlemi UYGULANMALIDIR?"

$5 \mathrm{Bu}$ soru şu kelimelerle ifadelendirilmiştir: "Çalıştı̆̆ınız şubedeki bir polis mensubunun böyle bir davranışta bulunması ve bu davranışının ortaya çıkmass durumunda, eğer bir disiplin işlemi uygulanacaksa, KURUMUNUZ TARAFINDAN hangi disiplin işlemi UYGULANIR?"

6 Bu soru şu kelimelerle ifadelendirilmiştir: "SİZ böyle bir davranışta bulunan bir polis mensubunu ihbar eder miydiniz?"

$7 \mathrm{Bu}$ soru şu kelimelerle ifadelendirilmiștir: "ÇALIȘTIĞINIZ ŞUBEDEKI POLIS MENSUPLARININ COĞU böyle bir davranıșta bulunan bir polis mensubunu ihbar eder miydi?"

8 Detaylı bir literatür incelemesi için bakınız; Kayabaşı, 2019:51-130.

9 Klockars ve arkadaşları tarafindan geliştirilen polis bütünlüğü anketinin birinci ve ikinci versiyonlarının kullanıldığı çalışmaların bir özeti için bakınız; Kayabaş1, 2019:130-132. 
ayrıca Narkotik ve Kaçakçıl1ğı Önleme Müdürlüğünün (Kayabaş1, 2017b), Adli Polis Müdürlüğünün (Kayabaş1, 2018a) ve Trafik Müdürlüğünün (Kayabaş1, 2018b) grupsal polis bütünlüğü düzeylerini keşfetmek üzere kullanılmıştır. Anketin ikinci versiyonu kullanılarak KKTC'deki polis bütünlüğünün diğer ülkelere nazaran sıralamasının ne durumda olduğunu tespite yönelik, KKTC'nin on ülke ile karşılaştırılmasına odaklanan bir çalışma (Kayabaşı, 2018d) da yapılmıştır. Diğer taraftan literatür tarandığında Türkçe literatürde bugüne değin KKTC'de büyük, orta ve küçük seviyelerdeki polis gruplarının polis bütünlüğü düzeylerinin karşılaştırılmasına odaklanan herhangi bir çalışmanın yapılmadığı görülmektedir. Bu çalışma ile söz konusu alana odaklanılmıştır.

\section{BULGULAR VE ANALIZ}

Bu başlık altında KKTC Polis Örgütü personelinin üç seviyede gruplar arası polis bütünlüğü düzeylerinin karşılaştırılması neticesinde elde edilen bulgulara ve bu bulguların analizine yer verilmiştir. Karşılaştırılan büyük seviyedeki gruplar; merkez örgütü ve taşra örgütü, orta seviyedeki gruplar; beş ilçe polis müdürlüğü ve küçük seviyedeki gruplar; İdari (Karakol), Adli, Trafik, İdari İşler ve Özlük İşleri, Muhaceret, GüvenlikKoruma, İletişim Bilgi İşlem, Özel Harekât, Siyasi/İstihbarat, Narkotik ve Kaçakçıllğı Önleme birimleridir.

\subsection{KKTC Polis Örgütünün, Merkez Örgütü ile Taşra Örgütünün Polis Bütünlüğü Düzeylerinin Karşılaştırılması}

Bu başlık altında H1 hipotezine cevap aranmıştır. KKTC Polis Örgütünün Merkez Örgütünde çalışan polislerin $(\mathrm{N}=295)$ polis bütünlüğü düzeylerinin, Taşra Örgütünde çalışan polislerin $(\mathrm{N}=867)$ polis bütünlüğü düzeylerinden anlamlı bir şekilde daha yüksek olup olmadığı, ölçümü yapılan yedi yönden 11 senaryoya 1162 polis tarafından verilen cevapların ortalaması üzerinden karşılaştırılmıştır. Elde edilen veriler üzerinde, aritmetik ortalama, standart sapma, bağımsız örneklemler t-testi analizleri yapılmıştır.

Tablo 1: KKTC Polis Örgütünün, Merkez Örgütü ve Taşra Örgütünün Polis Bütünlüğü Düzeylerinin Karşılaştırılması

\begin{tabular}{|c|c|c|c|c|c|c|}
\hline Karş1laştırılan Yönler & Örgüt & $\mathrm{N}$ & $\mathrm{x}$ & SS & $\mathrm{t}$ & $\mathrm{p}$ \\
\hline \multirow{2}{*}{ Kendi Ciddiyet Algıları } & Merkez & 295 & 3,74 & 0,59 & \multirow{2}{*}{1,057} & \multirow{2}{*}{0,291} \\
\hline & Taşra & 867 & 3,70 & 0,70 & & \\
\hline \multirow{2}{*}{ Kendilerine Göre Meslektaşlarının Ciddiyet Algıları } & Merkez & 295 & 3,64 & 0,59 & \multirow{2}{*}{$1,981 *$} & \multirow{2}{*}{0,048} \\
\hline & Taşra & 867 & 3,55 & 0,68 & & \\
\hline \multirow{2}{*}{ Resmi Kural İhlali Algıları } & Merkez & 295 & 3,79 & 0,66 & \multirow{2}{*}{1,481} & \multirow{2}{*}{0,139} \\
\hline & Taşra & 867 & 3,72 & 0,72 & & \\
\hline \multirow{2}{*}{ Destekledikleri Disiplin İşlemi } & Merkez & 295 & 3,82 & 0,69 & \multirow{2}{*}{1,542} & \multirow{2}{*}{0,123} \\
\hline & Taşra & 867 & 3,74 & 0,87 & & \\
\hline \multirow{2}{*}{ Bekledikleri Disiplin İşlemi } & Merkez & 295 & 3,81 & 0,74 & \multirow{2}{*}{0,027} & \multirow{2}{*}{0,978} \\
\hline & Taşra & 867 & 3,81 & 0,92 & & \\
\hline \multirow{2}{*}{ Kendi Bildirme İsteklilikleri } & Merkez & 295 & 3,29 & 0,67 & \multirow{2}{*}{$2,004 *$} & \multirow{2}{*}{0,045} \\
\hline & Taşra & 867 & 3,19 & 0,74 & & \\
\hline \multirow{2}{*}{ Kendilerine Göre Meslektaşlarının Bildirme İsteklilikleri } & Merkez & 295 & 3,33 & 0,65 & \multirow{2}{*}{$2,193 *$} & \multirow{2}{*}{0,029} \\
\hline & Taşra & 867 & 3,22 & 0,70 & & \\
\hline
\end{tabular}

Bağımsız örneklemler t-testi:*p<0,05; **p<0,01;***p<0,001

Katılımcıların yedi yönden on bir senaryoya verdikleri cevapların aritmetik ortalamaları, standart sapmaları ve bağımsız örneklemler t-testi sonuçları Tablo 1'de verilmiştir. Tablo 1'e göre, katılımcıların "kendilerine göre meslektaşlarının ciddiyet algıları" [t $\mathrm{t}(1160)=1,981, \mathrm{p}<0,05]$, "kendi bildirme isteklilikleri" [t(1160) = 2,004, $\mathrm{p}<0,05]$ ve "kendilerine göre meslektaşlarının bildirme isteklilikleri" [ $\mathrm{t}(1160)=2,193, \mathrm{p}<0,05]$ yönlerinden polis bütünlüğü düzeyleri, Merkez veya Taşrada çalışma durumlarına göre anlamlı bir şekilde farklılık göstermektedir. $\mathrm{Bu}$ üç yönden ortalama değerler incelendiğinde; Merkez Örgütünde çalışan polislerin polis bütünlüğü düzeylerinin, Taşra Örgütünde çalışan polislerin polis bütünlüğü düzeylerinden anlamlı bir şekilde daha yüksek olduğu görülmektedir. Katılımcıların "kendi ciddiyet algıları" [t(1160) =1,057, p>0,05], "resmi kural ihlali algıları" [t(1160) $=1,481, \mathrm{p}>0,05]$ "destekledikleri disiplin işlemi”" [t(1160) $=1,542, \mathrm{p}>0,05]$ ve "bekledikleri disiplin işlemi” [ $\mathrm{t}(1160)=0,027, \mathrm{p}>0,05]$ yönlerinden polis bütünlüğü düzeyleri ise, Merkez veya Taşrada çalışma durumlarına göre anlamlı bir şekilde farklılık göstermemektedir. 


\subsection{KKTC Polis Örgütünün İlçe Polis Müdürlüklerinin Polis Bütünlüğü Düzeylerinin Karşılaştırılması}

Bu başlık altında H2 hipotezine cevap aranmıştır. KKTC Polis Örgütünün taşra örgütünde çalışan polislerin polis bütünlügü düzeylerinin, çalıştıkları İlçe Polis Müdürlüklerine göre anlamlı bir şekilde farklılık gösterip göstermediği, ölçümü yapılan yedi yönden 11 senaryoya 867 polis tarafindan verilen cevapların ortalaması üzerinden karşılaştırılmıştır. Elde edilen veriler üzerinde, aritmetik ortalama, standart sapma, varyans analizi, Levene testi ve çoklu karşılaştırma testleri yapılmıştır.

Tablo 2: KKTC Polis Örgütünün İlçe Polis Müdürlüklerinin Polis Bütünlüğü Düzeylerinin Karşılaştırılması

\begin{tabular}{|c|c|c|c|c|c|c|c|}
\hline Karşılaştırılan Yönler & İlçe Polis Müdürlüğü & $\mathrm{N}$ & $\mathrm{x}$ & SS & $\mathrm{F}$ & $\mathrm{p}$ & Fark \\
\hline \multirow{5}{*}{ Kendi Ciddiyet Algıları } & (1) Lefkoşa & 354 & 3,64 & 0,69 & \multirow{5}{*}{$4,385^{*}$} & \multirow{5}{*}{0,002} & \multirow{5}{*}{$\begin{array}{l}1-2 \\
2-3\end{array}$} \\
\hline & (2) Gazimağusa & 212 & 3,84 & 0,62 & & & \\
\hline & (3) Girne & 79 & 3,59 & 0,83 & & & \\
\hline & (4) Güzelyurt & 90 & 3,82 & 0,69 & & & \\
\hline & (5) İskele & 132 & 3,62 & 0,67 & & & \\
\hline \multirow{5}{*}{$\begin{array}{l}\text { Kendilerine Göre Meslektaşlarının } \\
\text { Ciddiyet Algıları }\end{array}$} & (1) Lefkoşa & 354 & 3,50 & 0,65 & \multirow{5}{*}{$5,888 *$} & \multirow{5}{*}{0,000} & \multirow{5}{*}{$\begin{array}{l}1-2 \\
1-4 \\
2-3 \\
3-4\end{array}$} \\
\hline & (2) Gazimağusa & 212 & 3,68 & 0,62 & & & \\
\hline & (3) Girne & 79 & 3,41 & 0,82 & & & \\
\hline & (4) Güzelyurt & 90 & 3,74 & 0,65 & & & \\
\hline & (5) İskele & 132 & 3,46 & 0,64 & & & \\
\hline \multirow{5}{*}{ Resmi Kural İhlali Algıları } & (1) Lefkoşa & 354 & 3,66 & 0,66 & \multirow{5}{*}{$2,671 *$} & \multirow{5}{*}{0,031} & \multirow{5}{*}{$1-2$} \\
\hline & (2) Gazimağusa & 212 & 3,84 & 0,66 & & & \\
\hline & (3) Girne & 79 & 3,66 & 0,95 & & & \\
\hline & (4) Güzelyurt & 90 & 3,80 & 0,69 & & & \\
\hline & (5) İskele & 132 & 3,69 & 0,66 & & & \\
\hline \multirow{5}{*}{ Destekledikleri Disiplin İşlemi } & (1) Lefkoşa & 354 & 3,67 & 0,81 & \multirow{5}{*}{$3,132 *$} & \multirow{5}{*}{0,014} & \multirow{5}{*}{$1-2$} \\
\hline & (2) Gazimağusa & 212 & 3,89 & 0,87 & & & \\
\hline & (3) Girne & 79 & 3,63 & 1,00 & & & \\
\hline & (4) Güzelyurt & 90 & 3,85 & 0,97 & & & \\
\hline & (5) İskele & 132 & 3,75 & 0,73 & & & \\
\hline \multirow{5}{*}{ Bekledikleri Disiplin İşlemi } & (1) Lefkoşa & 354 & 3,76 & 0,90 & \multirow{5}{*}{$2,692 *$} & \multirow{5}{*}{0,030} & \multirow{5}{*}{$2-3$} \\
\hline & (2) Gazimağusa & 212 & 3,93 & 0,87 & & & \\
\hline & (3) Girne & 79 & 3,65 & 1,07 & & & \\
\hline & (4) Güzelyurt & 90 & 3,95 & 0,97 & & & \\
\hline & (5) İskele & 132 & 3,80 & 0,73 & & & \\
\hline \multirow{5}{*}{ Kendi Bildirme İsteklilikleri } & (1) Lefkoşa & 354 & 3,12 & 0,63 & \multirow{5}{*}{$5,469^{*}$} & \multirow{5}{*}{0,000} & \multirow{5}{*}{$\begin{array}{l}1-2 \\
2-3\end{array}$} \\
\hline & (2) Gazimağusa & 212 & 3,35 & 0,80 & & & \\
\hline & (3) Girne & 79 & 3,05 & 0,79 & & & \\
\hline & (4) Güzelyurt & 90 & 3,33 & 0,80 & & & \\
\hline & (5) İskele & 132 & 3,12 & 0,76 & & & \\
\hline \multirow{5}{*}{$\begin{array}{l}\text { Kendilerine Göre Meslektaşlarının } \\
\text { Bildirme İsteklilikleri }\end{array}$} & (1) Lefkoşa & 354 & 3,15 & 0,62 & \multirow{5}{*}{$5,169 *$} & \multirow{5}{*}{0,000} & \\
\hline & (2) Gazimağusa & 212 & 3,37 & 0,71 & & & \\
\hline & (3) Girne & 79 & 3,11 & 0,83 & & & $\begin{array}{l}1-2 \\
2-3\end{array}$ \\
\hline & (4) Güzelyurt & 90 & 3,37 & 0,75 & & & \\
\hline & (5) İskele & 132 & 3,22 & 0,62 & & & \\
\hline
\end{tabular}

Katılımcıların yedi yönden on bir senaryoya verdikleri cevapların aritmetik ortalamaları, standart sapmaları, varyans analizi ve çoklu karşılaştırma testi sonuçları Tablo 2'de verilmiştir. Tablo 2'ye göre, KKTC Polis Örgütünün taşra örgütünde çalışan katılımcıların "kendi ciddiyet algıları" [F $(4,862)=4,385, p<0,05]$, "kendilerine göre meslektaşlarının ciddiyet algıları" $[\mathrm{F}(4,862)=5,888, \mathrm{p}<0,05]$, "resmi kural ihlali algıları" $[\mathrm{F}(4,862)=2,671, \mathrm{p}<0,05]$, "destekledikleri disiplin işlemi" $[\mathrm{F}(4,862)=3,132, \mathrm{p}<0,05]$, "bekledikleri disiplin işlemi $[\mathrm{F}(4,862)=2,692, \mathrm{p}<0,05]$, "kendi bildirme isteklilikleri" $[\mathrm{F}(4,862)=5,469, \mathrm{p}<0,05]$ ve "kendilerine 
göre meslektaşlarının bildirme isteklilikleri’ $[\mathrm{F}(4,862)=5,169, \mathrm{p}<0,05]$ yönlerinden polis bütünlüğü düzeyleri, çalıştıkları İlçe Polis Müdürlüklerine göre anlamlı bir şekilde farklılık göstermektedir.

Katılımcıların yedi yönden on bir senaryoya verdikleri cevapların aritmetik ortalamaları, standart s "Kendi ciddiyet algıları" yönünden; ortalama değerler, varyans analizi ve çoklu karşılaştırma testinin sonuçlarına bakıldığında, Gazimağusa Polis Müdürlüğünde çalışan polislerin polis bütünlüğü düzeylerinin; Lefkoşa ve Girne Polis Müdürlüklerinde çalışan polislerin polis bütünlüğü düzeylerinden anlamlı bir şekilde farkl1lık gösterdiği ve daha yüksek olduğu görülmektedir.

"Kendilerine göre meslektaşlarının ciddiyet algıları” yönünden; ortalama değerler, varyans analizi ve çoklu karşılaştırma testinin sonuçlarına bakıldığında, Gazimağusa ve Güzelyurt Polis Müdürlüklerinde çalışan polislerin polis bütünlüğü düzeylerinin, Lefkoşa ve Girne Polis Müdürlüklerinde çalışan polislerin polis bütünlüğü düzeylerinden anlamlı bir şekilde farklılık gösterdiği ve daha yüksek olduğu görülmektedir.

"Resmi kural ihlali algıları" ve "destekledikleri disiplin işlemi” yönlerinden; ortalama değerler, varyans analizi ve çoklu karşılaştırma testinin sonuçlarına bakıldığında, Gazimağusa Polis Müdürlüğünde çalışan polislerin polis bütünlüğu düzeylerinin, Lefkoşa Polis Müdürlüğünde çalışan polislerin polis bütünlüğü düzeylerinden anlamlı bir şekilde farklılık gösterdiği ve daha yüksek olduğu görülmektedir.

"Bekledikleri disiplin işlemi” yönünden ortalama değerler, varyans analizi ve çoklu karşılaştırma testinin sonuçlarına bakıldığında, Gazimağusa Polis Müdürlüğünde çalışan polislerin polis bütünlüğü düzeylerinin, Girne Polis Müdürlüğünde çalışan polislerin polis bütünlüğü düzeylerinden anlamlı bir şekilde farklılık gösterdiği ve daha yüksek olduğu görülmektedir.

"Kendi bildirme isteklilikleri" ve "kendilerine göre meslektaşlarının bildirme isteklilikleri” yönlerinden; ortalama değerler, varyans analizi ve çoklu karşılaştırma testinin sonuçlarına bakıldığında, Gazimağusa Polis Müdürlüğünde çalışan polislerin polis bütünlügü düzeylerinin, Lefkoşa ve Girne Polis Müdürlüklerinde çalışan polislerin polis bütünlüğü düzeylerinden anlamlı bir şekilde farklılık gösterdiği ve daha yüksek olduğu görülmektedir.

\subsection{KKTC Polis Örgütünün Çeşitli Birimlerinin Polis Bütünlüğü Düzeylerinin Karşılaştırılması}

$\mathrm{Bu}$ başlık altında H3 hipotezine cevap aranmıştır. KKTC Polis Örgütünde çalışan polislerin polis bütünlüğü düzeylerinin, çalıştıkları birimlere göre anlamlı bir şekilde farklılık gösterip göstermediği, ölçümü yapılan yedi yönden 11 senaryoya 1149 polis tarafından verilen cevapların ortalaması üzerinden karşılaştırılmışırı. Elde edilen veriler üzerinde, aritmetik ortalama, standart sapma, varyans analizi, Levene testi ve çoklu karşılaştırma testleri yapılmıştır.

Katılımcıların yedi yönden on bir senaryoya verdikleri cevapların aritmetik ortalamaları, standart sapmaları, varyans analizi sonuçları ve çoklu karşılaştırma testi sonuçları Tablo 3'de verilmiştir. Tablo 3'e göre, katılımcıların "kendi ciddiyet algıları" $[\mathrm{F}(9,1139)=3,564, \mathrm{p}<0,05]$, "kendilerine göre meslektaşlarının ciddiyet algiları" [F $(9,1139)=4,649, \mathrm{p}<0,05]$, "resmi kural ihlali algiları" $[\mathrm{F}(9,1139)=3,171, \mathrm{p}<0,05]$ "destekledikleri disiplin işlemi" $[\mathrm{F}(9,1139)=4,115, \mathrm{p}<0,05]$, "bekledikleri disiplin işlemi $[\mathrm{F}(9,1139)=3,474$, $\mathrm{p}<0,05]$, "kendi bildirme isteklilikleri" $[\mathrm{F}(9,1139)=5,472, \mathrm{p}<0,05]$ ve "kendilerine göre meslektaşlarının bildirme isteklilikleri” $[\mathrm{F}(9,1139)=5,063, \mathrm{p}<0,05]$ yönlerinden polis bütünlüğü düzeyleri, çalıştıkları birimlere göre anlamlı bir şekilde farklılık göstermektedir.

"Kendi ciddiyet algıları" yönünden; ortalama değerler, varyans analizi ve çoklu karşılaştırma testinin sonuçlarına bakıldığında, "trafik" birimlerinde çalışan polislerin polis bütünlüğü düzeylerinin; "adli" ve "siyasi/istihbarat" birimlerde çalışan polislerin polis bütünlüğü düzeylerinden anlamlı bir şekilde farklılık gösterdiği ve daha düşük olduğu görülmektedir. Kendi ciddiyet algıları" yönünden ayrıca "muhaceret" birimlerinde çalışan polislerin polis bütünlüğü düzeylerinin; "siyasi/istihbarat" birimlerinde çalışan polislerin polis bütünlüğü düzeylerinden anlamlı bir şekilde farklılık gösterdiği ve daha düşük olduğu da görülmektedir.

"Kendilerine göre meslektaşlarının ciddiyet algıları" yönünden; ortalama değerler, varyans analizi ve çoklu karşılaştırma testinin sonuçlarına bakıldığında, "siyasi/istihbarat" birimlerinde çalışan polislerin polis bütünlüğü düzeylerin; "trafik", "muhaceret" ve "güvenlik veya koruma" birimlerinde çalışan polislerin polis bütünlüğü düzeylerinden anlamlı bir şekilde farklılık gösterdiği ve daha yüksek olduğu görülmektedir. Bu yönden ayrıca "adli” birimlerde çalışan polislerin polis bütünlüğü düzeylerin de "trafik" birimlerinde çalışan polislerin polis bütünlüğü düzeylerinden anlamlı bir şekilde farkl1lık gösterdiği ve daha yüksek olduğu da görülmektedir. 
Tablo 3: KKTC Polis Örgütünün Çeşitli Birimlerinin Polis Bütünlüğü Düzeylerinin Karşılaştırılması

\begin{tabular}{|c|c|c|c|c|c|c|c|}
\hline Karş1laştırılan Yönler & Birim & $\mathrm{N}$ & $\mathrm{x}$ & SS & $\mathrm{F}$ & $\mathrm{p}$ & Fark \\
\hline \multirow{10}{*}{$\begin{array}{l}\text { Kendi Ciddiyet } \\
\text { Alg1lar1 }\end{array}$} & (1) İdari (Karakol) & 260 & 3,70 & 0,62 & \multirow{10}{*}{$3,564 *$} & \multirow{10}{*}{0,000} & \multirow{10}{*}{$\begin{array}{l}2-3 \\
3-9 \\
5-9\end{array}$} \\
\hline & (2) Adli & 234 & 3,78 & 0,74 & & & \\
\hline & (3) Trafik & 154 & 3,53 & 0,77 & & & \\
\hline & (4) İdari İşler ve Özlük İşleri & 60 & 3,84 & 0,72 & & & \\
\hline & (5) Muhaceret & 51 & 3,51 & 0,42 & & & \\
\hline & (6) Güvenlik-Koruma & 217 & 3,69 & 0,70 & & & \\
\hline & (7) İletişim-Bilgi İşlem & 22 & 3,92 & 0,59 & & & \\
\hline & (8) Özel Harekât & 67 & 3,64 & 0,52 & & & \\
\hline & (9) Siyasi/istihbarat & 55 & 3,97 & 0,49 & & & \\
\hline & (10) Narkotik ve Kaçakçılığı Önleme & 30 & 3,81 & 0,57 & & & \\
\hline \multirow{10}{*}{$\begin{array}{l}\text { Kendilerine Göre } \\
\text { Meslektaşlarının } \\
\text { Ciddiyet Algıları }\end{array}$} & (1) İdari (Karakol) & 260 & 3,57 & 0,57 & \multirow{10}{*}{$4,649 *$} & \multirow{10}{*}{0,000} & \multirow{10}{*}{$\begin{array}{l}2-3 \\
3-9 \\
5-9 \\
6-9\end{array}$} \\
\hline & (2) Adli & 234 & 3,66 & 0,74 & & & \\
\hline & (3) Trafik & 154 & 3,40 & 0,73 & & & \\
\hline & (4) İdari İşler ve Özlük İşleri & 60 & 3,72 & 0,64 & & & \\
\hline & (5) Muhaceret & 51 & 3,44 & 0,43 & & & \\
\hline & (6) Güvenlik-Koruma & 217 & 3,50 & 0,68 & & & \\
\hline & (7) İletişim-Bilgi İşlem & 22 & 3,86 & 0,58 & & & \\
\hline & (8) Özel Harekât & 67 & 3,56 & 0,53 & & & \\
\hline & (9) Siyasi/istihbarat & 55 & 3,86 & 0,50 & & & \\
\hline & (10) Narkotik ve Kaçakçılığı Önleme & 30 & 3,79 & 0,56 & & & \\
\hline \multirow{10}{*}{$\begin{array}{l}\text { Resmi Kural İhlali } \\
\text { Algıları }\end{array}$} & (1) İdari (Karakol) & 260 & 3,73 & 0,64 & \multirow{10}{*}{$3,171 *$} & \multirow{10}{*}{0,001} & \multirow{10}{*}{$3-9$} \\
\hline & (2) Adli & 234 & 3,79 & 0,76 & & & \\
\hline & (3) Trafik & 154 & 3,55 & 0,85 & & & \\
\hline & (4) İdari İşler ve Özlük İşleri & 60 & 3,88 & 0,71 & & & \\
\hline & (5) Muhaceret & 51 & 3,63 & 0,50 & & & \\
\hline & (6) Güvenlik-Koruma & 217 & 3,74 & 0,69 & & & \\
\hline & (7) İletişim-Bilgi İşlem & 22 & 3,96 & 0,77 & & & \\
\hline & (8) Özel Harekât & 67 & 3,70 & 0,63 & & & \\
\hline & (9) Siyasi/istihbarat & 55 & 4,05 & 0,47 & & & \\
\hline & (10) Narkotik ve Kaçakçılığı Önleme & 30 & 3,77 & 0,66 & & & \\
\hline \multirow{10}{*}{$\begin{array}{l}\text { Destekledikleri } \\
\text { Disiplin İşlemi }\end{array}$} & (1) İdari (Karakol) & 260 & 3,77 & 0,76 & \multirow{10}{*}{$4,115^{*}$} & \multirow{10}{*}{0,000} & \multirow{10}{*}{$\begin{array}{l}1-3 \\
2-3 \\
3-6 \\
3-9 \\
5-9 \\
8-9\end{array}$} \\
\hline & (2) Adli & 234 & 3,85 & 0,95 & & & \\
\hline & (3) Trafik & 154 & 3,49 & 0,91 & & & \\
\hline & (4) İdari İşler ve Özlük İşleri & 60 & 3,87 & 0,74 & & & \\
\hline & (5) Muhaceret & 51 & 3,60 & 0,62 & & & \\
\hline & (6) Güvenlik-Koruma & 217 & 3,79 & 0,88 & & & \\
\hline & (7) İletişim-Bilgi İşlem & 22 & 3,88 & 0,73 & & & \\
\hline & (8) Özel Harekât & 67 & 3,62 & 0,59 & & & \\
\hline & (9) Siyasi/istihbarat & 55 & 4,14 & 0,58 & & & \\
\hline & (10) Narkotik ve Kaçakçılığı Önleme & 30 & 3,88 & 0,58 & & & \\
\hline \multirow{9}{*}{$\begin{array}{l}\text { Bekledikleri Disiplin } \\
\text { İşlemi }\end{array}$} & (1) İdari (Karakol) & 260 & 3,84 & 0,82 & \multirow{9}{*}{$3,474^{*}$} & \multirow{9}{*}{0,000} & \multirow{9}{*}{$\begin{array}{l}1-3 \\
2-3 \\
3-9\end{array}$} \\
\hline & (2) Adli & 234 & 3,92 & 0,97 & & & \\
\hline & (3) Trafik & 154 & 3,53 & 1,03 & & & \\
\hline & (4) İdari İşler ve Özlük İşleri & 60 & 3,95 & 0,72 & & & \\
\hline & (5) Muhaceret & 51 & 3,73 & 0,65 & & & \\
\hline & (6) Güvenlik-Koruma & 217 & 3,81 & 0,90 & & & \\
\hline & (7) İletişim-Bilgi İşlem & 22 & 3,86 & 0,89 & & & \\
\hline & (8) Özel Harekât & 67 & 3,58 & 0,64 & & & \\
\hline & (9) Siyasi/istihbarat & 55 & 4,07 & 0,67 & & & \\
\hline
\end{tabular}




\begin{tabular}{|c|c|c|c|c|c|c|c|}
\hline & (10) Narkotik ve Kaçakçılığı Önleme & 30 & 3,88 & 0,58 & & & \\
\hline \multirow{10}{*}{$\begin{array}{l}\text { Kendi Bildirme } \\
\text { İsteklilikleri }\end{array}$} & (1) İdari (Karakol) & 260 & 3,17 & 0,69 & \multirow{10}{*}{$5,472^{*}$} & \multirow{10}{*}{0,000} & \multirow{10}{*}{$\begin{array}{l}1-9 \\
2-9 \\
3-9 \\
4-9 \\
5-9 \\
6-9 \\
8-9\end{array}$} \\
\hline & (2) Adli & 234 & 3,28 & 0,78 & & & \\
\hline & (3) Trafik & 154 & 3,05 & 0,74 & & & \\
\hline & (4) İdari İşler ve Özlük İşleri & 60 & 3,28 & 0,75 & & & \\
\hline & (5) Muhaceret & 51 & 3,13 & 0,47 & & & \\
\hline & (6) Güvenlik-Koruma & 217 & 3,18 & 0,75 & & & \\
\hline & (7) İletişim-Bilgi İşlem & 22 & 3,32 & 0,81 & & & \\
\hline & (8) Özel Harekât & 67 & 3,11 & 0,58 & & & \\
\hline & (9) Siyasi/istihbarat & 55 & 3,76 & 0,50 & & & \\
\hline & (10) Narkotik ve Kaçakçılığı Önleme & 30 & 3,44 & 0,59 & & & \\
\hline \multirow{10}{*}{$\begin{array}{c}\text { Kendilerine Göre } \\
\text { Meslektaşlarının } \\
\text { Bildirme İsteklilikleri }\end{array}$} & (1) İdari (Karakol) & 260 & 3,24 & 0,62 & \multirow{10}{*}{$5,063 *$} & \multirow{10}{*}{0,000} & \multirow{10}{*}{$\begin{array}{c}1-9 \\
2-9 \\
3-9 \\
3-10 \\
4-9 \\
5-9 \\
6-9 \\
8-9\end{array}$} \\
\hline & (2) Adli & 234 & 3,29 & 0,74 & & & \\
\hline & (3) Trafik & 154 & 3,08 & 0,78 & & & \\
\hline & (4) İdari İşler ve Özlük İşleri & 60 & 3,26 & 0,64 & & & \\
\hline & (5) Muhaceret & 51 & 3,18 & 0,47 & & & \\
\hline & (6) Güvenlik-Koruma & 217 & 3,20 & 0,70 & & & \\
\hline & (7) İletişim-Bilgi İşlem & 22 & 3,47 & 0,78 & & & \\
\hline & (8) Özel Harekât & 67 & 3,21 & 0,60 & & & \\
\hline & (9) Siyasi/istihbarat & 55 & 3,71 & 0,54 & & & \\
\hline & (10) Narkotik ve Kaçakçılığı Önleme & 30 & 3,55 & 0,55 & & & \\
\hline \multicolumn{8}{|c|}{ F testi: $* \mathrm{p}<0,05$} \\
\hline
\end{tabular}

"Resmi kural ihlali algıları" yönünden; ortalama değerler, varyans analizi ve çoklu karşılaştırma testinin sonuçlarına bakıldığında, "siyasi/istihbarat" birimlerinde çalışan polislerin polis bütünlüğü düzeylerin; "trafik" birimlerinde çalışan polislerin polis bütünlüğ̈̈ düzeylerinden anlamlı bir şekilde farklılık gösterdiği ve daha yüksek olduğu görülmektedir.

"Destekledikleri disiplin işlemi" yönünden; ortalama değerler, varyans analizi ve çoklu karşılaştırma testinin sonuçlarına bakıldığında, "trafik" birimlerinde çalışan polislerin polis bütünlüğü düzeylerin; "idari (karakol)", "adli", "güvenlik veya koruma" ve "siyasi/istihbarat" birimlerinde çalışan polislerin polis bütünlügü düzeylerinden anlamlı bir şekilde farklılık gösterdiği ve daha düşük olduğu görülmektedir. Bu yönden ayrıca "trafik", "muhaceret" ve "özel harekât" birimlerinde çalışan polislerin polis bütünlüğü düzeylerinin; "siyasi/istihbarat" birimlerinde çalı̧̧an polislerin polis bütünlüğü düzeylerinden anlamlı bir şekilde farkl1lık gösterdiği ve daha düşük olduğu da görülmektedir.

"Bekledikleri disiplin işlemi" yönünden; ortalama değerler, varyans analizi ve çoklu karşılaştırma testinin sonuçlarına bakıldığında, "trafik" birimlerinde çalışan polislerin polis bütünlüğü düzeylerin; "idari (karakol)", "adli" ve "siyasi/istihbarat" birimlerinde çalışan polislerin polis bütünlüğü düzeylerinden anlamlı bir şekilde farkl1l1k gösterdiği ve daha düşük olduğu görülmektedir.

"Kendi bildirme isteklilikleri" yönünden; ortalama değerler, varyans analizi ve çoklu karşılaştırma testinin sonuçlarına bakıldığında, "siyasi/istihbarat" birimlerinde çalışan polislerin polis bütünlüğü düzeylerinin; "idari (karakol)", "adli", "trafik", "idari işler ve özlük işleri", "muhaceret", "güvenlik veya koruma" ve "özel harekât" birimlerinde çalışan polislerin polis bütünlüğü düzeylerinden anlamlı bir şekilde farklılık gösterdiği ve daha yüksek olduğu görülmektedir.

"Kendilerine göre meslektaşlarının bildirme isteklilikleri” yönünden; ortalama değerler, varyans analizi ve çoklu karşılaştırma testinin sonuçlarına bakıldığında, "siyasi/istihbarat" birimlerinde çalışan polislerin polis bütünlüğü düzeylerinin; "idari (karakol)", "adli”, "trafik", "idari işler ve özlük işleri’, "muhaceret”, "güvenlik veya koruma" ve "özel harekât" birimlerinde çalışan polislerin polis bütünlüğü düzeylerinden anlamlı bir şekilde farklılık gösterdiği ve daha yüksek olduğu görülmektedir. Bu yönden ayrıca "narkotik ve kaçakçılığı önleme" birimlerinde çalışan polislerin polis bütünlüğü düzeylerinin; "trafik" birimlerinde çalışan polislerin polis bütünlüğü düzeylerinden anlamlı bir şekilde farkl1lık gösterdiği ve daha yüksek olduğu da görülmektedir. 


\section{SONUÇ VE ÖNERILER}

KKTC Polis Örgütü polislerin, yedi yönden karşılaştırılan polis bütünlüğü düzeylerinin, grupsal özelliklerine göre farklılaşıp farklılaşmadığına ve eğer farklılaşmışsa bu farkın kaynağının ne olduğuna yönelik ulaşılan sonuçları şu şekilde özetlemek mümkündür;

(1) Merkez Örgütü veya Taşra Örgütünde çalışma durumuna göre: Katılımcıların polis bütünlüğü düzeyleri, karşılaștırıldıkları yedi yönün üçünde (kendilerine göre meslektaşlarının ciddiyet algıları, kendi bildirme isteklilikleri ve kendilerine göre meslektaşlarının bildirme isteklilikleri), merkez veya taşrada çalışma durumlarına göre anlamlı bir şekilde farklılık göstermektedir. Merkez birimlerde çalışan polislerin polis bütünlügü düzeyleri, karşılaştırıldıkları bu üç yönden, taşradaki birimlerde çalışan polislere oranla daha yüksek bir düzeydedir. Geri kalan dört yönden ise (kendi ciddiyet algıları, resmi kural ihlali algıları, destekledikleri disiplin işlemi, bekledikleri disiplin işlemi), polislerin merkezde veya taşrada çalışma durumlarına göre polis bütünlüğü düzeyleri anlamlı bir şekilde farklılık göstermemektedir. Merkez ve Taşra örgütleri seviyesindeki karşılaştırmada belirgin olarak ortaya çıkan husus; Merkez Örgütünde çalışan polislerin polis bütünlüğü düzeylerinin, Taşra Örgütünde çalışan polislerin polis bütünlüğü düzeylerinden daha yüksek bir seviyede olduğudur.

(2) Çalış1lan İlçe Polis Müdürlüklerine göre: Katılımcıların polis bütünlüğü düzeyleri, karşılaştırıldığı yedi yönden de çalıştıkları İlçe Polis Müdürlüklerine göre anlamlı bir şekilde farklılık göstermektedir. Bu anlamlı farklılığın kaynağı ile ilgili şu sonuçlara ulaşılmıştır;

- Kendi ciddiyet algıları, kendi bildirme isteklilikleri ve kendilerine göre meslektaşlarının bildirme isteklilikleri yönlerinden; Gazimağusa Polis Müdürlüğünün polis bütünlüğü düzeyi, Lefkoşa ve Girne Polis Müdürlüklerinden daha yüksektir.

- Kendilerine göre meslektaşlarının ciddiyet algıları yönünden; Gazimağusa ve Güzelyurt Polis Müdürlüklerinin polis bütünlüğü düzeyi, Lefkoşa ve Girne Polis Müdürlüklerinden daha yüksektir.

- Resmi kural ihlali algıları ve destekledikleri disiplin işlemi yönlerinden; Gazimağusa Polis Müdürlüğünün polis bütünlüğü düzeyi, Lefkoşa Polis Müdürlüğünden daha yüksektir.

- Bekledikleri disiplin işlemi yönünden; Gazimağusa Polis Müdürlüğünün polis bütünlüğü düzeyi, Girne Polis Müdürlügünden daha yüksektir.

İlçe Polis Müdürlükleri seviyesindeki karşılaştırmada belirgin olarak ortaya çıkan husus; Gazimağusa Polis Müdürlügünün grupsal polis bütünlüğü düzeyinin genel olarak diğer İlçe Polis Müdürlüklerinden daha yüksek bir seviyede olduğu ve Girne Polis Müdürlüğünün grupsal polis bütünlüğü düzeyinin genel olarak diğer İlçe Polis Müdürlüklerinden daha düşük bir seviyede olduğudur.

(3) Çalışılan birimlere göre: Katılımcıların polis bütünlüğü düzeyleri, karşılaştırıldıkları yedi yönden de çalıştıkları birimlere göre anlamlı bir şekilde farklılık göstermektedir. Bu farklılığın en temel kaynağı, karşılaştırıldıkları yedi yönden de diğer birimlerden anlamlı bir şekilde farklılık gösteren "siyasi/istihbarat" ve "trafik" birimleridir. Polis birimleri seviyesindeki karşılaştırmada belirgin olarak ortaya çıkan husus; bir taraftan "siyasi/istihbarat" birimlerinin polis bütünlüğü düzeylerinin genel olarak diğer birimlerden daha yüksek bir seviyede olduğu; diğer taraftan "trafik" birimlerinin polis bütünlüğü düzeylerinin ise genel olarak diğer birimlerden daha düşük bir seviyede olduğudur.

$\mathrm{Bu}$ araştırma ile polis sapması sorununun KKTC özelinde grupsal boyutu araştırılmış ve büyük gruplardan küçük gruplara doğru, üç seviyede risk altındaki gruplar tespit edilmeye çalışılmıştır. Ulaşılan bulgular, büyük seviyede, taşra örgütünün, orta seviyede Girne Polis Müdürlüğünün ve küçük seviyede ise trafik birimlerinin polis bütünlügü düzeylerinin kendi seviyelerinde karşılaştırıldıkları gruplardan anlamlı bir şekilde farklılaştıklarını ve daha düşük düzeyde polis bütünlüğüne sahip olduklarını ortaya çıkarmıştır. Bu gruplar, polis sapmasına karşı en fazla risk altında olan gruplardır. Hizmet içi eğitim planlaması yapılırken bu durumun göz önünde bulundurulması şüphesiz bu grupların polis bütünlüğü düzeylerinin yükselmesine katkı sağlayacaktır. Fakat özelde her bir seviyede risk altında olan grupların, polis bütünlüğü düzeylerinin düşüklüğünün kendi seviyelerine has nedenleri ve bu nedenlere bağlı çözüm yolları aranabileceği de bir gerçektir. Sözkonusu grupların polis bütünlüğü düzeylerinin neden karşılaştırıldıkları diğer grupların polis bütünlüğü düzeylerinden anlamlı bir şekilde daha düşük düzeyde polis bütünlüğüne sahip oldukları hususu ise farklı çalışmaların konusudur. 
$\mathrm{Bu}$ çalışma ile polis sapmasının; 'uygunsuz ikinci iş yapma/ticari faaliyette bulunma' (Senaryo 1) , 'yetki yozlaşması' (Senaryo 2 ve 4), 'rüşvetçilik' (Senaryo 3), 'fırsat hırsılılı̆ı' (Senaryo 5 ve 11), 'komisyonculuk' (Senaryo 6), 'kurum içi rüşvet ilişkisi' (Senaryo 7), 'kılıfına uydurma/kapatma' (Senaryo 8), 'yasa dışı faaliyetleri koruma' (Senaryo 9) ve 'sivillere karşı polis şiddeti' (Senaryo 10) türlerine karşı, yedi yönden, üç seviyede grupsal olarak polislerin polis bütünlüğü düzeyleri araştırılmıştır. Bu alanda ileride yapılacak olan çalışmalarda polis sapmasının diğer türlerine (örneğin doğrudan suç faaliyetlerinde bulunma, delil yerleştirme, itirafa zorlama, ifadeyi yönlendirme, yüce amaç disiplin suçu, polis şiddetinin diğer türleri olan küfürlü dil kullanımı ve ölümcül güç kullanımı gibi) karşı da, polislerin polis bütünlüğü düzeyleri araştırılabilir. İngilizce literatürde hem polis sapması hem de polis bütünlügüü üzerine çok sayıda bilimsel araştırma yapılmasına karşın, Türkçe literatürde bu alanda yeterince çalışmanın yapılmadığı görülmektedir. Türkçe literatürün zenginleştirilmesi adına bu alanda yapılacak çalışmaların teşvik edilip desteklenmesi gerektiği de değerlendirilmektedir.

\section{KAYNAKÇA}

BÜYÜKÖZTÜRK, Şener (2012), “Örnekleme Yöntemleri”, Balıkesir Üniversitesi Kurumsal Web Sitesi, http://w3.balikesir.edu.tr/ msackes/wp/wp-content/uploads/2012/03/BAY-Final-Konulari.pdf (Erişim Tarihi: 30.12.2020).

GÜRBÜZ, Sait ve ŞAHIN, Faruk (2016), Sosyal Bilimlerde Araştırma Yöntemleri: Felsefe - Yöntem Analiz, Seçkin Yayıncılık, Ankara, 3.Baskı.

INTERNATIONAL TEST COMMISSION (2005), International Guidelines on Test Adaptation, https://www.intestcom.org/files/guideline_test_adaptation.pdf (Erişim Tarihi: 27.04.2015).

KAYABAŞI, Cem (2012), "KKTC'de Polis Teşkilatının Meşruiyet Seviyesi Üzerine Bir Araştırma", Yayımlanmamış Yüksek Lisans Tezi, LAÜ Sosyal Bilimler Enstitüsü, Lefke (KKTC).

KAYABAŞI, Cem (2020), "Kuzey Klbrls Türk Cumhuriyeti'nde Polis Meşruiyeti Faktörlerinin Polisle İşbirliğine Etkisi”, Yayımlanmamış Doktora Tezi, Polis Akademisi Güvenlik Bilimleri Enstitüsü, Ankara.

KAYABAŞI, Osman (2012), “KKTC Polis Örgütü Etikliğinin Toplumsal Algllanma Düzeyi Üzerine Bir Araştırma”, Yayımlanmamış Yüksek Lisans Tezi, LAÜ Sosyal Bilimler Enstitüsü, Lefke (KKTC).

KAYABAŞI, Osman (2017a), "The Contours of Police Integrity in the Turkish Republic of Northern Cyprus", Symposium Book- Social Science- Volume I (Ed. Abidin Temizer ve Sevilay Özer), Gece Kitaplığı Yayınları, Ankara, ss.153-193.

KAYABAŞI, Osman (2017b), "Police Integrity in the Turkish Republic of Northern Cyprus: Narcotics and Prevention of Smuggling Directorate Police Officers' Perceptions", Turkish Journal of Security Studies, S.19(Special Issue), ss.100-129.

KAYABAŞI, Osman (2018a), "Police Integrity in the Turkish Republic of Northern Cyprus: Criminal Investigation Directorate Police Officers' Perceptions", The Journal of Academic Social Science Studies, S.67(Spring III), ss.509-528.

KAYABAŞI, Osman (2018b), "Police Integrity in the Turkish Republic of Northern Cyprus: Traffic Directorate Police Officers' Perceptions", Multidisciplinary Studies-3 (Social Sciences) (Ed. Hasan Babacan, A. Şevki Duymaz ve Abidin Temizer), Gece Kitaplığı Yayını, Ankara, ss.459-488.

KAYABAȘI, Osman (2018c), "Police Integrity in the Turkish Republic of Northern Cyprus: Guzelyurt Police Directorate Police Officers' Perceptions”, Multidisciplinary Studies-3 (Social Sciences), (Ed. Hasan Babacan, A. Şevki Duymaz ve Abidin Temizer), Gece Kitaplığ Yayını, Ankara, ss.489-515.

KAYABAŞI, Osman (2018d), "Polis Meslek Ahlakı Bütünlüğ̈̈ Üzerine Karşıllaştırmalı Bir Bakış”, Akademik Sosyal Araştırmalar Dergisi, S.6(66), ss.542-563.

KAYABAŞI, Osman (2019), "Polis Sapmasina Karşı Polis Bütünlüğü Perspektifinden Kuzey Kıbrıs Türk Cumhuriyeti Polis Örgütü”, Yayımlanmamış Doktora Tezi, Polis Akademisi Güvenlik Bilimleri Enstitüsü, Ankara. 
KAYABAŞI, Osman (2020a), “Örgütsel Polis Bütünlüğ̈̈ ile Grupsal Polis Bütünlüğü Üzerine Karşılaştırmalı Bir Baklş: Kuzey Kıbrıs Türk Cumhuriyeti Polis Örgütü ile Lefke Polis Karakolu Örneği”, II. Lefke Kent Sempozyumu Bildiriler Kitabı -2 (Ed. Orhan Gemikonakl1, Makbule Oktay ve Teoman Oktay), TipografART Yayınları, Lefke (KKTC), ss.75-89.

KAYABAŞI, Osman (2020b), "Polis Bütünlügü̈ Üzerine Teorik Bir İnceleme ve Polis Sapması Sorununa Karşı Bütüncül Bir Yaklaşım”, R\&S - Research Studies Anatolia Journal, S.3(4), ss.343-359.

KAYABAŞI, Osman (2020c), "Polis Sapmast Üzerine Teorik Bir Inceleme", EUropean Journal of Managerial Research (EUJMR), S.4(7), ss.264-285.

KAYABAŞI, Osman (2020d), "Polis Örgütlerinin Örgütsel Polis Bütünlüğü Düzeyleri Üzerine Uluslararası Boyutta Karşılaştırmalı Bir Bakış", Uluslararası CEO (İletişim, Ekonomi, Organizasyon) Sosyal Bilimler Kongresi Bildiriler Kitabı, 18-20 Aralık 2020 - Bosna Hersek, Gorazde Üniversitesi Yayını.

KAYABAŞI, Osman ve TEKİNER, Mehmet Ali (2017a), “Kuzey Kıbrıs Türk Cumhuriyeti’nde Sürekli İkamet Edenlerin Polis Meslek Etiği Kapsamında Polis Algısının Ölçülmesi”, Türk İdare Dergisi, S.89(485), ss.665-694.

KAYABAŞI, Osman ve TEKİNER, Mehmet Ali (2017b), "Kuzey Kıbrıs Türk Cumhuriyeti Polis Örgütünün Polis Meslek Ahlakı Bütünlügü”, 25. Ulusal Yönetim ve Organizasyon Kongresi Bildiriler Kitabı (Ed. Esra Aydın, Papatya Sevgin Bıçakcı ve Erdem Kırkbeşoğlu), Başkent Üniversitesi Yayını, Ankara, ss.657-662.

KKTC FOKUS (2012), “Kuzey Kıbrıs Kamu Çalışanları Araştırması”, KKTC Devletinde Fonksiyonel ve Kurumsal Gözden Geçirme Projesi, 2010-2012 Kamunun Etkinliği ve Özel Sektörün Rekabet Gücünün Artırılması Programı, Lefkoşa (KKTC).

KLOCKARS, Carl B., KUTNJAK, Ivković Sanja ve HABERFELD, Maria R. (2006), Enhancing Police Integrity, Springer Publisher, New York (USA).

KNAPP KOMISYONU (1972), Knapp Commission Report on Police Corruption, George Braziller Publisher, New York (USA).

O'CONNOR, Tara R. (2005), Police Deviance and Ethics, Mega Links in Criminal Justice, http://faculty.ncwc.edu/toconnor/205/205lect11.htm (Erişim Tarihi: 23.09.2020).

PUNCH, Maurice (2003), “Rotten Orchards: 'Pestilence', Police Misconduct and System Failure”, Policing and Society, S.13(2), ss.171-196. 